\title{
A milestone in the doubled haploid pathway of cassava
}

\section{A milestone in the doubled haploid pathway of cassava (Manihot esculenta Crantz): cellular and molecular assessment of anther-derived structures}

\author{
P. I. P. Perera • C. A. Ordoñez • \\ L. A. Becerra Lopez-Lavalle • B. Dedicova
}

Received: 11 July 2013 / Accepted: 20 August 2013 /Published online: 13 September 2013

(C) The Author(s) 2013. This article is published with open access at Springerlink.com

\begin{abstract}
This study was aimed at inducing androgenesis in cultured anthers of cassava (Manihot esculenta Crantz) to develop a protocol for the production of doubled haploids. Microspore reprogramming was induced in cassava by cold or heat stress of anthers. Since the anthers contain both haploid microspores and diploid somatic cells, it was essential to verify the origin of anther-derived calli. The origin of antherderived calli was assessed by morphological screening followed by histological analysis and flow cytometry (FCM). Additionally, simple sequence repeat (SSR) and amplified fragmented length polymorphism (AFLP) assays were used for the molecular identification of the microspore-derived calli. The study clearly demonstrated the feasibility of producing microspore-derived calli using heat- or cold-pretreated anthers. Histological studies revealed reprogramming of the developmental pathway of microspores by symmetrical division of the nucleus. Flow cytometry analysis revealed different ploidy level cell types including haploids, which confirmed their origin from the microspores. The SSR and AFLP marker assays independently confirmed the histological and FCM results of a haploid origin of the calli at the DNA level. The presence of multicellular microspores in the in vitro system indicated a switch of developmental program, which constitutes a crucial step in the design of protocols for the regeneration of microspore-derived embryos and plants. This is the first detailed report of calli, embryos, and abnormal
\end{abstract}

Handling Editor: Peter Nick

P. I. P. Perera $(\bowtie) \cdot$ C. A. Ordoñez $\cdot$ L. A. B. Lopez-Lavalle $\cdot$

B. Dedicova

Agrobiodiversity Research Area, International Center for Tropical

Agriculture, A.A. 6713, Cali, Colombia

e-mail: p.perera@cgiar.org

P. I. P. Perera

e-mail: prasanthi1970@yahoo.com shoots originated from the haploid cells in cassava, leading to the development of a protocol for the production of doubled haploid plants in cassava.

Keywords Androgenesis $\cdot$ Amplified fragment length polymorphism (AFLP) · Flow cytometry · Histology · Microspore reprogramming $\cdot$ Simple sequence repeat (SSR)

\section{Introduction}

Cassava (Manihot esculenta Crantz), a perennial of the dicotyledonous family Euphorbiaceae and domesticated for its starchy roots, is a basic dietary component of millions of people. While considered as a "poor man's crop" because it is mainly consumed by people living under the poverty line in Africa, Asia, and Latin America, in recent years, cassava's impact on the starch industry has been huge worldwide (Davis et al. 2003). Cassava grows well under marginal conditions such as in drought-prone and low-fertility soils where few other crops could survive (Ceballos et al. 2010) and has recently been referred to as the "Rambo root" because of its resilience (Herrmann 2012) and ability to adapt to almost all climatic conditions. It can be harvested 6 to 24 months after planting, making it very useful as a food security crop. In addition, interest in cassava has grown because of its potential to be used in the emerging bioethanol industry.

It is importance to improve this crop both in terms of its nutritional value and its productivity. The former will benefit the millions who depend on it as the main source of nutrition, while enhancing productivity is imperative if the future demand for food under the anticipated impact of climate change is to be met. Compared with the other crops, numerous constraints such as length of improvement cycle and the heterozygous nature of the plant make it difficult and inefficient to 
produce improved cassava hybrids using conventional breeding methods (Ceballos et al. 2010). These breeding programs also require a large area of land and high labor input to evaluate segregating progenies.

The production of homozygous lines in cassava will significantly impact and accelerate the production of new hybrids. However, the development of such lines has so far been hindered by the difficulties encountered in generating homozygous parental types (Dunwell et al. 2010). Doubled haploid techniques are commonly used to produce homozygous lines in a single generation. The establishment of completely homozygous lines opens the possibility of numerous other applications such as induced mutations, chromosome reduction of polyploid species, gene or quantitative trait loci mapping, genomics, and transformation experiments. It also enables the exploitation of important recessive traits that are desirable for incorporation into hybrids.

In general, the culture of anthers, pollen, ovaries, and ovules produces haploid regenerants as fixed gametoclonal variants resulting from meiosis. However, microspore embryogenesis through in vitro anther culture is a method widely used to generate genetic variability by obtaining gametic embryos. Although androgenesis has been reported in more than 250 plant species (Ochatt and Zhang 1996), only few studies have been reported in cassava aimed at developing doubled haploid protocols, but with limited success. Even though the research have been conducted for more than three decades in the International Center for Tropical Agriculture (CIAT), the protocol is yet to be developed. Since 1970s, calli derived from the anthers (Moh 1975; Mukherjee 1996; Woodward and Puonti-Kaerlas 2001; Chirinos et al. 2006; $\mathrm{Xi}$ et al. 2009) and proembryoids derived from the microspores (Mukherjee and Naskar 2010) have been reported; however, their origin or the ploidy level has not been studied. Liu and Chen (1978) have obtained green calli from the anthers; however, they were derived from the somatic tissues. Thus, the attempts made for about four decades clearly demonstrate the difficulty of achieving success in the production of doubled haploids in cassava. Therefore, attempts were made in this research to develop a reproducible protocol that would result in the formation of multicellular microspores as a first step towards at haploid plant production via antherderived structures. Studies were conducted in depth to analyze the anthers and the anther-derived structures at a cellular level in order to understand if microspore reprogramming occurred by the culture conditions applied, as an indicator for androgenesis. Further attempts were made to induce embryogenesis in the anther-derived structures. Since anthers contain both haploid microspores and diploid somatic cells in the anther wall and connective tissue, it is essential to verify the origin of those anther-derived calli to use them for the regeneration of haploid or doubled haploid plants. Thus, the present study also aimed to determine the origin of anther-derived calli by flow cytometry analysis and molecular techniques such as simple sequence repeat (SSR) markers and amplified fragmented length polymorphism (AFLP), for confirmation of the origin of anther-derived calli in cassava.

\section{Materials and methods}

Donor plants and growth conditions

The commercial cassava genotype SM 1219-9 was used as the donor plant and was grown at two plots at CIAT headquarters. Plants were established at 15 -day intervals to stagger flowering throughout the year, thus facilitating the year-round collection of flowers for continuous research. Field management practices involved biological pest and disease control, mechanical weed control, zero or minimum application of agrochemicals, and sprinkler irrigation, to ensure good quality flowers for in vitro culture.

The immature racemes containing male buds were collected from the field before 9:00 a.m., and buds 2.3 to $2.6 \mathrm{~mm}$ in diameter were isolated and washed with soap and running tap water and dried on a filter paper for $10 \mathrm{~min}$. Well-drained buds were placed in a laminar flow hood and surface sterilized with $70 \%$ ethanol for $1 \mathrm{~min}$ followed by $10 \%$ Clorox $(v / v)$ with $60 \mu \mathrm{l} / \mathrm{l}$ Tween 20 for $20 \mathrm{~min}$. Disinfected buds were then washed four times, $2 \mathrm{~min}$ each, with autoclaved water.

\section{Androgenesis induction and development}

Ten treatments were established in a triplicate experiment (each containing 120 anthers per treatment), to determine the temperature shock that best induced androgenesis in the cultured cassava anthers. Twenty-four anthers were extracted from six sterilized buds (four anthers per bud) and cultured on a Petri dish $(60 \times 15 \mathrm{~mm})$ containing $10 \mathrm{ml}$ of liquid culture medium. Five Petri dishes were used per treatment. Treatments involved shock of cold at $10^{\circ} \mathrm{C}$ or heat at 34 and $38^{\circ} \mathrm{C}$, either alone, for 3 days, or combined pretreatments with cold followed by each heat shock (cold/heat; 1/3 days, $2 /$ 2 days, and 3/1 day). Non-pretreated anthers were used as the control treatment.

Filter-sterilized MS medium (Murashige and Skoog 1962) as modified by Lentini et al. (1995) was used as the basal medium (BM) throughout the study. The BM supplemented with $8 \mathrm{mg} / 1$ 2,4-dichlorophenoxyacetic acid (2,4-D), $800 \mathrm{mg} / 1$ glutamine, and $9 \%(w / v)$ sucrose was used for the induction of microspore embryogenesis within the anthers. After adjusting the $\mathrm{pH}$ to $5.8,500 \mathrm{mg} / 1$ 2-( $N$-morpholino)ethanesulfonic acid was added to the culture medium and then filter sterilized with a $0.45-\mu \mathrm{m}$ membrane filter (Thermo Scientific* Nalgene* Rapid-Flow). Cultures were maintained in the dark at $28^{\circ} \mathrm{C}$ without subculturing until a response was observed. The 
number of callus-bearing anthers was recorded. Based on the highest callusing frequency, the best temperature shock pretreatment was selected and used in four replications to check consistency. Once the anther-derived calli were visible in the liquid culture medium, they were transferred on to the BM solidified with $2.5 \%$ Phytagel $(w / v)$ containing $4 \%$ sucrose and $2 \mathrm{mg} / 1$ 2,4-D, for callus proliferation.

Calli derived from different anthers were maintained as separate individual lines. Small clumps of these friable calli were then subcultured onto the hormone-free BM medium solidified with $5 \%$ Phytagel $(w / v)$ for 2 weeks followed by the BM containing $2 \mathrm{mg} / \mathrm{l}$ 6-benzylaminopurine (BAP) and $0.5 \mathrm{mg} / \mathrm{l}$ naphthalene acetic acid (NAA) solidified with $2.5 \%$ Phytagel $(w / v)$ for a month. Then, the embryogenic structures were subcultured onto the same medium containing only $0.5 \mathrm{mg} / \mathrm{l} \mathrm{BAP}$ at 1-month intervals until the conversion of embryos occurred. The globular embryos were exposed to cool white fluorescent light at $88 \mu \mathrm{mol} \mathrm{m} \mathrm{m}^{-2}$.

\section{Statistical analysis}

Observations were made at biweekly intervals. The number of anther-derived calli was recorded, and the average androgenic response in cultured anthers was calculated as the number of callus-bearing anthers divided by the total number of anthers cultured. Data were analyzed using the statistical package SAS (SAS Institute Inc 1999). Chi-square or maximum likelihood ANOVA was conducted using the Proc CatMod procedures of PC/SAS. All possible treatment means were compared based on SE, $95 \%$ confidence intervals, or orthogonal contrast coefficients (Compton 1994). All experiments were analyzed as a completely randomized design, and all data were based on a minimum of three replicates per experiment per treatment.

Determination of the origin of anther-derived calli

The origin of anther-derived calli was studied by four independent analyses. The initiation of microspore embryogenesis and the subsequent embryogenesis pathway was studied at cellular level using the classical histological techniques. The origin of two batches of anther-derived callus lines was compared at least with two independent methods comprising of flow cytometry, SSR, or AFLP analysis.

\section{Histological analysis}

Anthers were sampled 2, 8, and 16 weeks after culture initiation. Histological analysis was performed on ten cultured anthers subjected to heat and cold pretreatments. Twenty anther-derived structures were also sampled at different stages of culture, ranging from friable calli to globular embryos. Samples were fixed in FAA (50 \% ethanol $+10 \%$ formaldehyde + glacial acetic acid, 18:1:1) for $72 \mathrm{~h}$ and then dehydrated through a graded ethanol series $(30,50,70,95$, and $100 \%, v / v$ ), followed by $100 \%$ butanol for $48 \mathrm{~h}$. After impregnation, samples were embedded in Technovit $8100^{\circledR}$ resin (Heraeus Kulzer GmbH, Wehrheim, Germany). Sections $3.5-5 \mu \mathrm{m}$ thick were obtained using a rotary microtome (Histostat, Reichert Scientific Instruments, NY, USA) and then were double stained with periodic acid Schiff's reagent (Sigma-Aldrich, Lyon, France) for starch- and protein-specific Naphthol Blue Black. All sections were studied under a light microscope (DM500; Leica GmbH, Wetzlar, Germany) and photographed with an attached camera (ICC50HD; Leica GmbH, Wetzlar, Germany).

\section{Flow cytometry}

Thirty anther-derived callus lines that resulted from cold pretreatment were analyzed using in vitro propagated SM 1219-9 donor plants as the control. Samples were analyzed according to Otto's method (1990). A small amount of leaf or callus tissue was finely chopped with a razor blade in $400 \mu \mathrm{l}$ extraction buffer ( $2.0 \%$ citric acid, $0.5 \%$ Tween 20 ) and filtered through a 30- $\mu \mathrm{m}$ mesh (Partec filter). Samples were kept on ice for no longer than $3 \mathrm{~h}$ until they are analyzed. Before flow cytometry, $1.6 \mathrm{ml}$ of staining solution was added that consisted of $2 \mathrm{mg} / \mathrm{ml}$ 4',6-diamidino-2-phenylindole (DAPI) in saturated dibasic sodium phosphate for a final DAPI concentration of $2.5 \mu \mathrm{g} / \mathrm{ml}$. To provide an unbiased relative measure of DNA content, all samples were co-chopped with leaf tissue of Trifolium repens cv. Nui as an internal standard. DAPI fluorescence was measured in the Partec PA-II flow cytometer with relative fluorescence compared with karyotyped in vitro control plants. Data were analyzed using the FlowMax software (Quantum Analysis, Münster, Germany). Ploidy was determined based on the diploid control material.

\section{SSR marker analysis}

Eight anther-derived callus lines from heat pretreatment $\left(38{ }^{\circ} \mathrm{C}\right)$ were randomly selected and analyzed to check the homozygous or heterozygous allele status of the antherderived callus lines using SSR DNA markers developed at CIAT by Mba et al. (2001). To confirm the homozygous allele status of the callus lines, only SSRs revealing heterozygous alleles in the donor plant SM 1219-9 were used. In total, 36 cassava SSR markers were screened in SM 1219-9 to develop an allele status molecular assay. DNA was extracted according to the plant DNA extraction protocol described by Doyle and Doyle (1990). The primer sequences of these cassava SSR markers are available from CIAT's Cassava Molecular Diversity Network (http://newapp.ciat.cgiar.org/molcas/).

Sequence-specific polymerase chain reactions (PCRs) were performed as described by Schuelke (2000) and 
Rampling et al. (2001) with the following modifications: a M13 (-21) primer was labeled with 6-FAM ${ }^{\mathrm{TM}}$, VIC ${ }^{\circledR}$, $\mathrm{NED}^{\mathrm{TM}}$, and $\mathrm{PET}^{\circledR}$ covalently bound to the $5^{\prime}$ end for the detection on the ABI 3130xl (Applied Biosystems, CA, USA). The unlabelled primers in each reaction consisted of an STS- or SSR-targeting forward primer with a $5^{\prime}$ M13 tail and a STS- or SSR-targeting reverse primer. After PCR amplification, four to eight amplification products were mixed according to size and labeling. The dilution factor of the PCR products differed according to the fluorescent label of the primer. Amplicons carrying the $6-\mathrm{FAM}^{\mathrm{TM}}$ or the $\mathrm{VIC}^{\circledR}$ fluorophores were diluted 300 times, and those carrying $\mathrm{NED}^{\mathrm{TM}}$ or $\mathrm{PET}^{\circledR}{ }^{\circledR}$ were diluted 150 times. Electropherograms were analyzed using the GeneMapper ${ }^{\circledR}$ version 4.0 software (Applied Biosystems, CA, USA).

\section{AFLP marker analysis}

The eight callus lines used for SSR analysis and a set of 21 lines analyzed by flow cytometry were further evaluated by ten AFLP markers. The AFLP method was performed as described by Vos et al. (1995), with minor modifications. The AFLP templates were prepared by digesting $1 \mu \mathrm{g}$ of genomic DNA with the restriction enzymes Eco RI and MseI for $2 \mathrm{~h}$ at $37^{\circ} \mathrm{C}$. Eco RI and Mse I adapters were ligated to the restriction fragments. Ligation reactions were conducted at $37{ }^{\circ} \mathrm{C}$ for $3 \mathrm{~h}$ and then held at $4{ }^{\circ} \mathrm{C}$ overnight. The preselective amplification (primers with one selective nucleotide) products were diluted 30-fold. The selective Eco RI and Mse I amplification primers carried three selective nucleotides (EACC, E-ACT, E-AGC, E-AGT, E-ACA, M-CAC, M-CAT, $\mathrm{M}-\mathrm{CTA}$, and $\mathrm{M}-\mathrm{CTG}$ ). Selective amplification products were loaded on $6 \%$ denaturing polyacrylamide gels run at $50 \mathrm{~W}$ for $2.5 \mathrm{~h}$ using $1 \times$ ethylenediaminetetraacetic acid (EDTA) (TTE) buffer (10.8 g Trizma base; $0.2 \mathrm{~g} \mathrm{Na}_{2}$ EDTA $2 \mathrm{H}_{2} \mathrm{O}$ ). The polyacrylamide was exposed to a silver nitrate developer prepared immediately before use as described by Bassam et al. (1991). The gels were fixed in $10 \%$ glacial acetic acid $(v / v)$ and $20 \%$ methanol $(v / v)$ for $30 \mathrm{~min}$, rinsed twice with $\mathrm{ddH}_{2} \mathrm{O}$, and dried at $65^{\circ} \mathrm{C}$ for $4 \mathrm{~h}$ to overnight. For dominant markers, such as AFLPs, only two states (present or absent) can be distinguished at each fragment position. Therefore, each fragment was scored as a locus with two alleles either present or absent.

\section{Results}

Androgenesis induction and development

In this study, androgenesis was induced in cultured cassava anthers by stressing them with any of above temperature shock, however, resulting different frequencies. In the absence of any stress conditions, the anthers initiated callus formation in the filament, anther wall, and connective tissues 1 week after inoculation. These calli proliferated extensively and filled the culture vessel within a month. In the coldpretreated anthers, calli emerged through the anther wall 2 months after inoculation. Some callus development from the connective tissues and filament was observed about 1 month after culture initiation, and those calli were removed as soon as possible. Late induction of callus was observed in the heat or heat/cold pretreatment combinations after 3-4 months. No somatic callus induction was observed in those anthers.

The highest percentage of callus-bearing anthers ( $25 \%)$ was recorded in cold-pretreated anthers (Fig. 1), being six times higher than that of heat-stressed anthers $\left(G^{2}=49 ; P<0.0001\right)$. No significant difference, however, was observed between the two heat shocks applied alone or with the combination of cold shock followed by heat shock at either $34{ }^{\circ} \mathrm{C}$ or $38^{\circ} \mathrm{C}$. However, a higher frequency of callus-bearing anthers was always observed with an increased duration of the cold shock, and four times more callus-bearing anthers were produced with 3 days of cold shock compared to the shortest cold shock lasting 1 day $\left(G^{2}=9.63 ; P<0.01\right)$. No significant difference was observed between the groups subjected to cold followed by heat at either 34 or $38^{\circ} \mathrm{C}$.

In this study, at the time of inoculation, the microspores were visible through the thin anther wall (Fig. 2a). When maintained continuously in the medium, the anther wall turned brown indicating cell death. Small globular structures emerged through a rupture in this dead anther wall (Fig. 2b) and started to proliferate (Fig. 2c). With the expansion of the callus, the rupture in the anther wall also expanded (Fig. 2d), and wall residues remained at the basal periphery of the proliferating callus (Fig. 2e). At this stage, further proliferation of the callus was induced by subculturing the callusbearing anthers on the solidified medium. All anthers contained highly friable and fragile calli (Fig. 2f). In the hormone-free medium, these calli further proliferated (Fig. 3a) increasing the mass of each callus line. Water stress created in the medium solidified with $5 \%$ Phytagel triggering compaction of the callus and induction of embryogenesis. These compact calli gave rise to globular embryos (Fig. 3b) in the presence of BAP and NAA in the culture medium. A higher tendency of secondary embryo production (Fig. 3c) was observed in the BAP supplemented medium giving rise to thousands of globular embryos. Upon exposure to the light, chlorophyll pigmentation (Fig. 3d) occurred in those embryos. However, conversion of the embryos into plants was not observed under the present culture conditions, whereas a low frequency of adventitious roots formation (Fig. 3e) and abnormal shoot (Fig. 3f) development was observed. 
Fig. 1 Callus induction frequency in the cultured anthers of cassava (M. esculenta Crantz) after application of cold and heat temperature shocks alone or in combination with both $(T 1$, without any temperature pretreatment; $T 2$, $10{ }^{\circ} \mathrm{C} ; \mathrm{T3}, 34^{\circ} \mathrm{C} ; \mathrm{T4}, 38^{\circ} \mathrm{C} ; \mathrm{T5}$ to $T 7$, combinations of 10 and $34^{\circ} \mathrm{C}$ for $1 / 3,2 / 2$, and $3 / 1$ days, respectively; $T 8$ to $T 10$, combinations of 10 and $38^{\circ} \mathrm{C}$ for $1 /$ $3,2 / 2$, and $3 / 1$ days, respectively).

Different letters above each bar indicate significantly different values at $P<0.05$

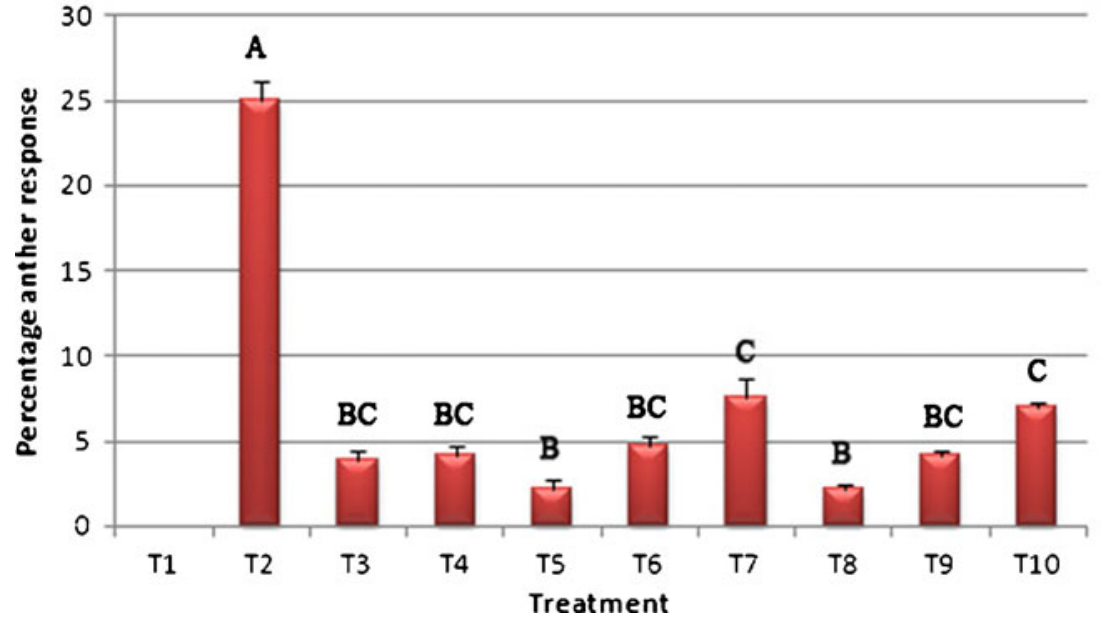

Determination of the origin of the anther-derived callus lines

\section{Histological analysis}

Anthers extracted from the flower buds $2.3-2.6 \mathrm{~mm}$ in diameter contained mid or late uninucleate microspores (Fig. 4a) as described by Perera et al. (2013). The wall cells of cultured anthers, epidermis, endothecium, and middle layer were enlarged (Fig. 4b, c) over the fresh ones. The nucleus of these cells was absent, ultimately leading to cell death (Fig. 4c). The tapetum was degenerated, and mitosis could not be observed in any of the anther wall cells. In contrast, the connective tissue of the anthers consisted of small meristematic cells with a high nuclear-to-cytoplasm ratio (Fig. 4c). This is comparable to morphological observations where callus production was observed from the connective tissues of the cultured anthers. Empty microspores were present in the pollen sacs of nonresponsive anthers (Fig. 4b, d) compared with fresh microspores found in fresh anthers (Fig. 4a). After 8 and 16 weeks, nuclei were absent in the majority of microspores (approximately $90 \%$ ) indicating their death. Nuclear divisions within the microspores indicated the induction of androgenesis.

Two different multicellular structure (MCS) developmental pathways were identified. In the first pathway, increased diameter of the induced microspores (Fig. 4d) over the non-induced microspores was a common feature. After symmetrical nuclear division occurred (Fig. 4e) 8 weeks after culture initiation, the cells were initially formed in the non-vacuolated region of the
Fig. 2 Morphological observations of anther-derived calli of cassava (M. esculenta Crantz) in the liquid culture medium. a Heat-pretreated anthers inoculated into the liquid culture medium. Note that the microspores are visible through the anther wall $($ bar $=800 \mu \mathrm{m})$. $\mathbf{b}$ Callus initiation. Note the callus emerging through the anther $(A n)$ wall (arrow) $($ bar $=500 \mu \mathrm{m})$. c Initial stage of callus development (bar $=420 \mu \mathrm{m})$. $\mathbf{d}-\mathbf{f}$ Different stages of callus $(\mathrm{Ca})$ proliferation. Note that the breaking point expands with the further development of the callus leaving the anther wall residues at the base of the proliferating callus (bars $=500$ and $500 \mu \mathrm{m}$ and $1 \mathrm{~mm})$

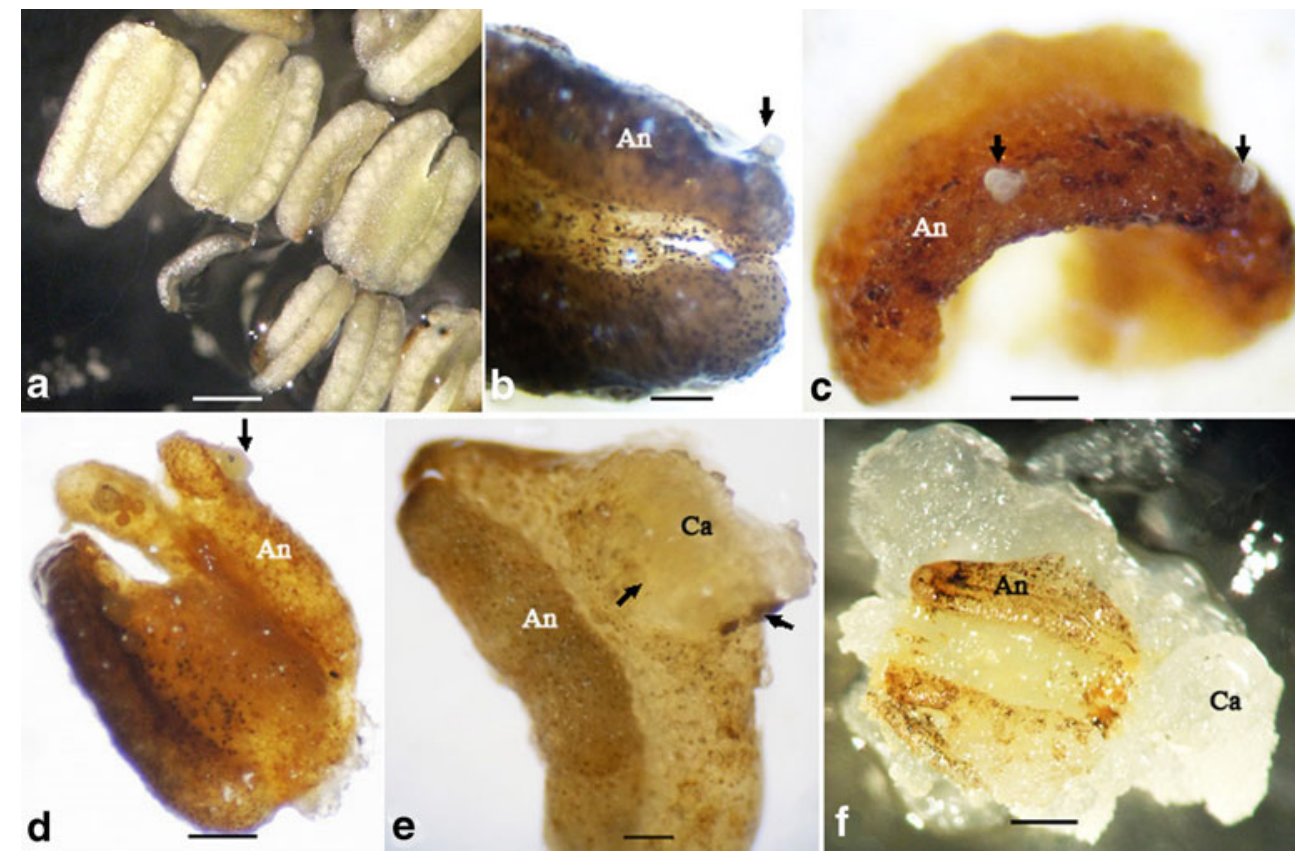



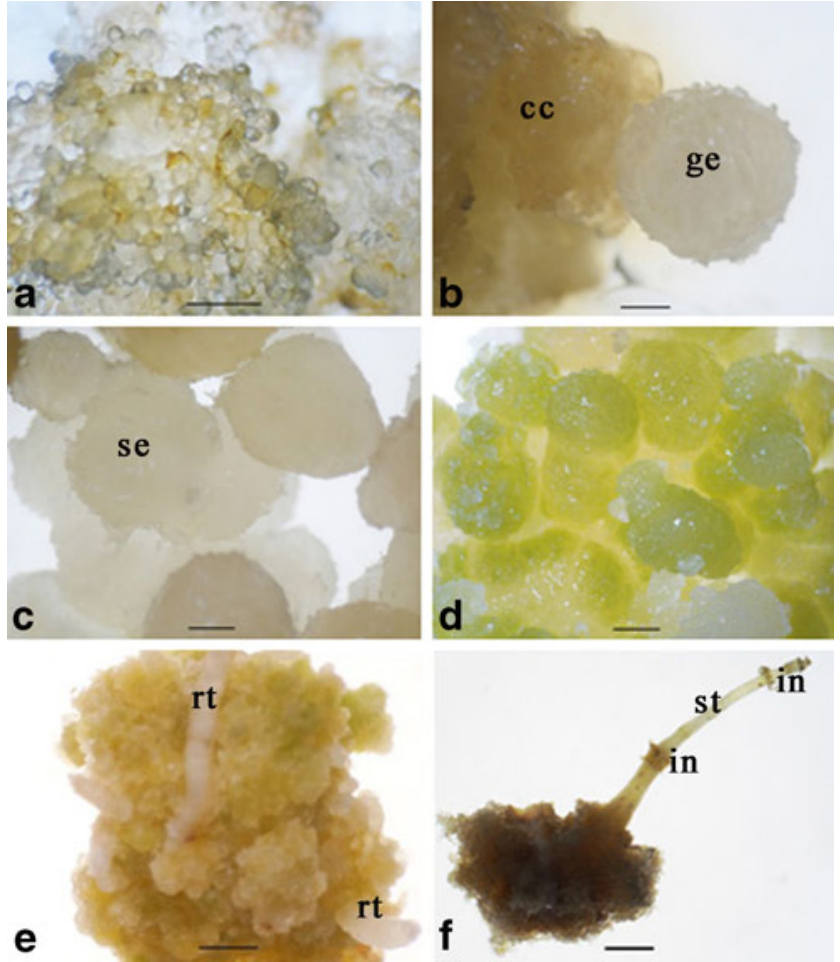

Fig. 3 Embryogenesis and conversion of embryos in cassava ( $M$. esculenta Crantz). a Friable callus in callus proliferation medium (bar $=1.4 \mathrm{~mm}$ ). b A globular embryo ( $g e$ ) derived from a compact callus (cc) after subculturing onto the hormone-free high Phytagel followed by BAP- and NAA-containing media (bar $=400 \mu \mathrm{m})$. c Secondary embryos (se) derived from the primary globular embryo $(800 \mu \mathrm{m})$. d Chlorophyll pigmentation in the secondary embryos after exposing to the light $(556 \mu \mathrm{m})$. e Adventitious root $(r t)$ development (bar $=2.7 \mathrm{~mm})$. f Abnormal shoot $(s t)$ development. Note the internodes (in) of the developing shoot $($ bar $=556 \mu \mathrm{m})$

microspore (Fig. 4f). The cells then grew to fill the entire space of the enlarged microspore (Fig. 4g, h) forming the MCS after 16 weeks. Contrastingly, microspore enlargement was not present in the second pathway. Nuclear division could be observed 2 weeks after culture initiation by the formation of two similar sized and shaped nuclei (Fig. 5a). The anthers analyzed 8 weeks after culture initiation contained a MCS with small cells with a high nuclear-to-cytoplasmic ratio (Fig. 5b). In both cases, the androgenesis induction frequency of the microspores was very low, limited to a maximum of two per anther. All the anther-derived calli showed loosely arranged cells indicating their high friability.

A sequence of embryogenesis events that occurred in the anther-derived friable calli was identified at cellular level. The presence of highly vacuolated undifferentiated parenchyma cells indicated the characteristic feature of friable calli (Fig. 6a). Proembryos (Fig. 6b) originated from single cells further enlarged in the hormone-free medium forming cell clusters with a remarkable isolation from a surrounding undifferentiated cell mass (Fig. 6c). These clusters developed into the embryos by initiating the differentiation of peripheral cells

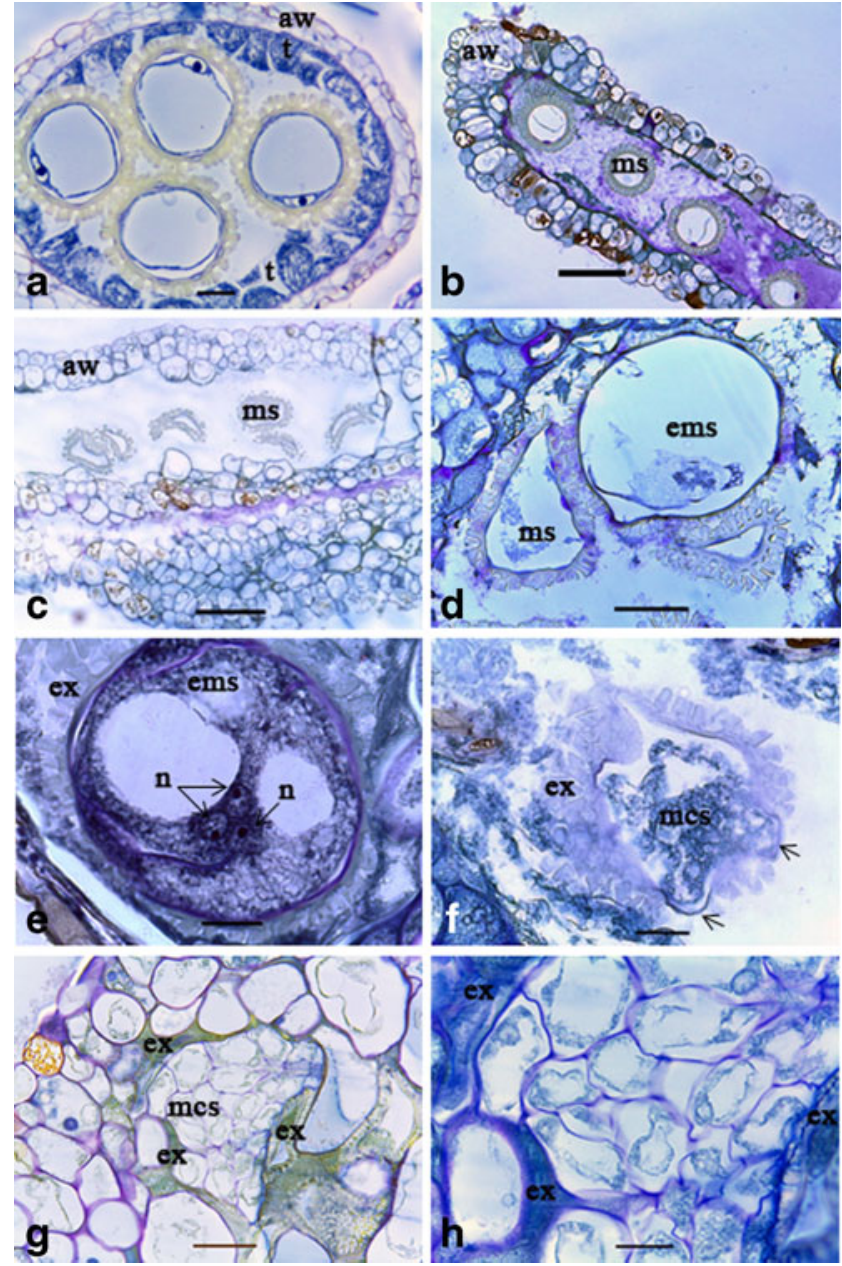

Fig. 4 Histological observations of androgenesis induction in cassava (M. esculenta Crantz). a Transverse section of a fresh anther containing late uninucleate microspores $(m s)(b a r=30 \mu \mathrm{m})$. Note the anther wall (aw) with four cell layers of epidermis, endothecium, middle layer, and the prominent tapetum $(t)$. b Cultured anther containing non-induced microspores $(m s)$ after 4 weeks $($ bar $=120 \mu \mathrm{m})$. Note that the anther wall cells became spherical/oblong in shape, and the tapetum is degenerating. c Dead microspores in the non-induced anther $($ bar $=120 \mu \mathrm{m})$. d Enlarged microspore $(\mathrm{ems})$. Note the small size non-induced microspores in the pollen sac $($ bar $=50 \mu \mathrm{m})$. e Nuclear $(n)$ division occurred in an enlarged microspore. Note that the three nuclei present in the cytoplasm are available, whereas the other nucleus is in another plane (not shown) $($ bar $=20 \mu \mathrm{m})$. f Multicellular structure in the exine matrix of the induced microspore (bar $=40 \mu \mathrm{m})$. Note the developing multicellular structure growing through the aperture of the exine (arrowhead). $g$ Multicellular structure containing a number of cells $($ bar $=50 \mu \mathrm{m})$. Note that the remaining exine (ex) particles are at the periphery of the multicellular structure. $\mathbf{h}$ Higher magnification of the multicellular structure $($ bar $=40 \mu \mathrm{m})$

(Fig. 6d). With the enlargement of embryos, further differentiation of the cells into different tissues could be identified (Fig. 6e, f). Finally, the developing globular embryo separated from the rest of the degenerating cell mass (Fig. $6 \mathrm{~g}$ ) and developed into an individual independent embryo. The fully grown embryos containing the vascular bundles were observed 
Fig. 5 Histological observations of androgenesis induction in cassava (M. esculenta Crantz). a Nuclear division (arrows) in the induced microspore $($ bar $=50 \mu \mathrm{m})$. b Induced microspore containing a MCS $($ bar $=20 \mu \mathrm{m})$. Note that the multicellular structure $(\mathrm{mcs})$ is developing through the aperture (a) of exine (ex)
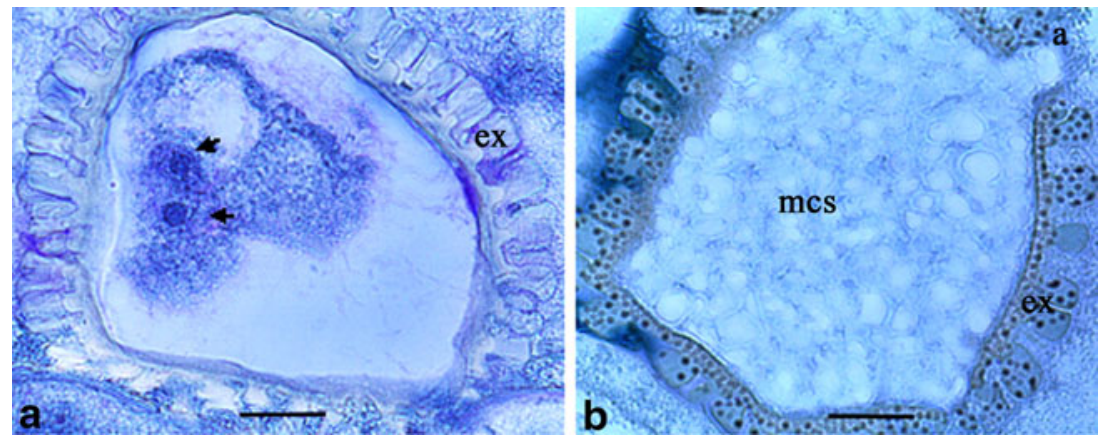
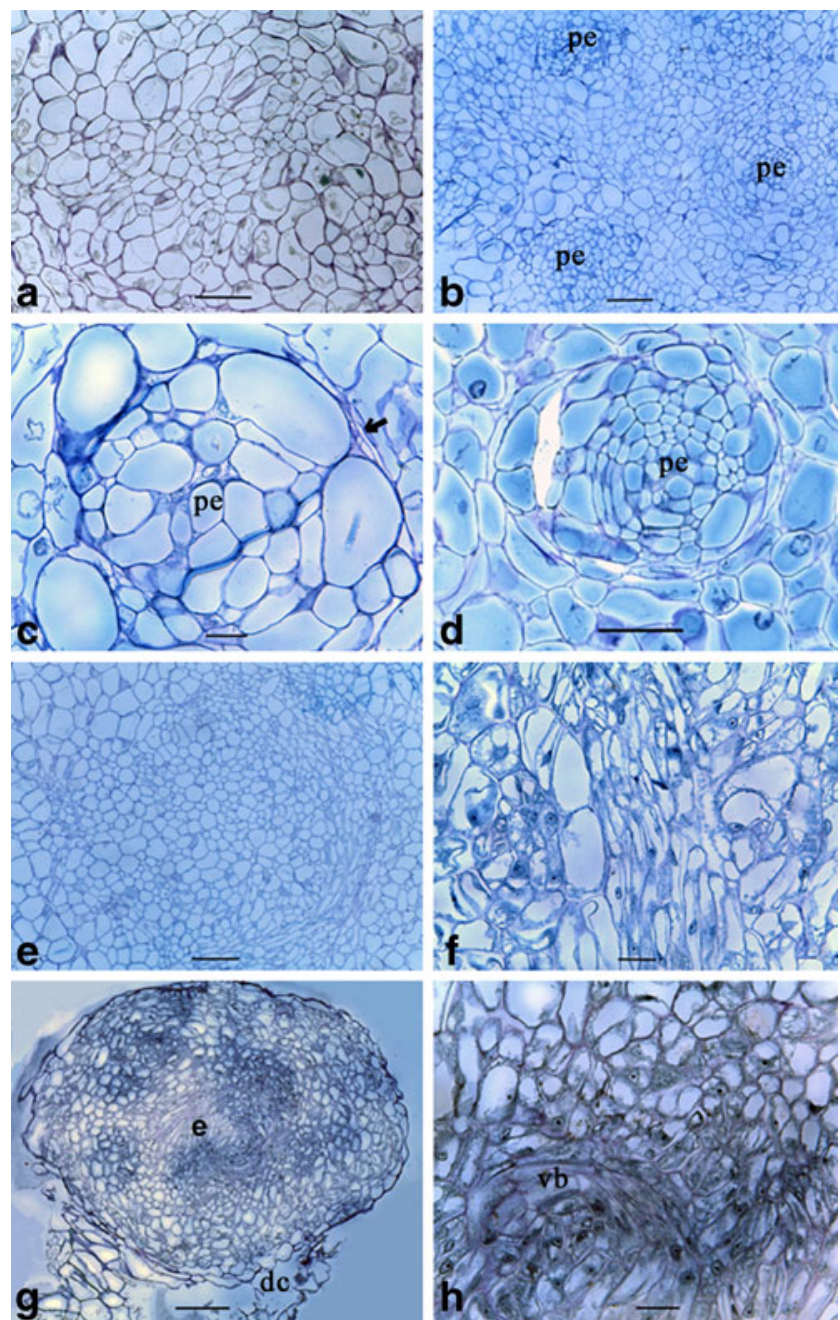

Fig. 6 Histological observations of embryogenesis in anther-derived calli of cassava ( $M$. esculenta Crantz). a Undifferentiated friable callus with the parenchyma cells. $\mathbf{b}$ The isolation of cell clusters from the other parenchyma cells giving rise to proembryos (pe). c An isolated proembryo under the higher magnification. Note the margin (arrow) that demarcates the proembryo. $\mathbf{d}$ The differentiation occurred in the peripheral cells of the proembryo converting them to elongated shape. e The differentiation of cells in the proembryo was continued with the cellular arrangement of the developing proembryo under higher magnification. $\mathbf{f}$ The degrading parenchyma cells $(d c)$ losing contact with the developing embryo $(e)$. g Formation of the vascular bundles $(v b)$. Bars are as follows: $\mathbf{a}, \mathbf{b}, \mathbf{e}, \mathbf{g}=150 \mu \mathrm{m} ; \mathbf{c}, \mathbf{f}, \mathbf{h}=30 \mu \mathrm{m}$; and $\mathbf{d}=100 \mu \mathrm{m}$
(Fig. 6h), and the complete embryos with shoot and root poles were not found among the analyzed anther-derived structures.

\section{Flow cytometry}

The ploidy levels of 21 anther-derived callus lines were compared with the internal standard T. repens "Huia" and a control of donor mother plants. The assumption was made that the mother plant contains a diploid chromosome complement of $2 n=2 x=36$. The flow cytometry analysis revealed the different ploidy levels, haploids $(n=x=18)$, diploids, and mixoploids (haploids and diploids), among the anther-derived callus lines (Table 1). Haploid histograms indicated the microspore origin of the calli in cultured anthers. The diploids were either homozygous or heterozygous. This study clearly indicated that some of the microspores in the cold-pretreated anthers reprogrammed for entering in to the sporophytic pathway give rise to haploid or mixoploid calli as indicated by a haploid peak. This set of 21 callus lines was further assessed by AFLP markers to study the feasibility of using the tool for ploidy analysis as an alternative to the flow cytometric analysis.

\section{SSR marker analysis}

The SSR marker assay was established to assess its feasibility for identifying the origin of anther-derived calli of cassava. This was proposed under the assumption that callus lines showing only one allele form will indicate microspore cell origin. This assay was carried out with a set of eight antherderived calli obtained from the heat pretreatment at $38^{\circ} \mathrm{C}$. A total of 36 SSR markers were screened to select those showing a heterozygous allele status in the donor plants (SM 1219-9). Even though one marker has proven sufficient for this purpose as reported by Perera et al. (2008b), in this study, all six SSRs were used to validate the diagnostic system's accuracy, and this is the first attempt of using this tool for assessing the homozygous status in cassava.

SSRs (SSRY 19, SSRY 21, SSRY 63, SSRY 82, SSRY 164 , and SSRY 182) showed the distinguishable heterozygous pattern of the donor plant with two alleles (Table 2). These biallelic diagnostic SSRs were used to assess the eight anther- 
Table 1 Flow cytometry analysis of cassava (M. esculenta Crantz) anther-derived calli

\begin{tabular}{|c|c|c|c|c|}
\hline \multirow[t]{2}{*}{ Resulted ploidy levels of the anther-derived calli from the donor plant } & \multicolumn{2}{|c|}{$\begin{array}{l}\text { Average DNA content at } \\
\text { the relevant peak of } \\
\text { histograms }\end{array}$} & \multirow[t]{2}{*}{ Average ratio of the peaks } & \multirow[t]{2}{*}{$\begin{array}{l}\text { Percentage of calli with } \\
\text { relevant ploidy level }\end{array}$} \\
\hline & IRS & Sample & & \\
\hline SM 1219-9 (donor plant-diploid control) & 304.00 & 190.67 & 0.63 & \\
\hline Haploid callus & 297.22 & 91.67 & 0.31 & 33.3 \\
\hline Diploid callus & 265.62 & 167.38 & 0.63 & 42.9 \\
\hline \multicolumn{5}{|l|}{ Mixoploid callus } \\
\hline $\mathrm{P} 1$ & 287.80 & 89.80 & 0.31 & 23.8 \\
\hline $\mathrm{P} 2$ & & 189.20 & 0.65 & \\
\hline
\end{tabular}

A total of 21 calli were analyzed. In vitro cultured cassava leaves of SM 1219-9 were used as the diploid control $(2 n=2 x=36)$ and $T$. repens Huia $(2 n=4 x=32)$ was used as the internal reference standard

IRS internal reference standard, $P$ peak

derived callus lines. The SSR analysis (i.e., SSRY 21, SSRY 63, and SSRY 182) showed a distinguishable monoallelic distribution when compared to the mother plant (Table 2, Fig. 7), which strongly suggests a potential haploid origin of the anther-derived calli. Also, the presence of novel alleles in the SSR profiling suggesting changes in the DNA sequence was observed. For instance, SSRY 19 showed a shared allele at $230 \mathrm{bp}$ between the mother plant and callus cell 2 (C2); however, a novel allele at 206 bp appeared, indicating that changes occurred at the DNA level that affected the number of repeats in this SSR allele region. Similarly, SSRY 82 and SSRY 164 showed changes at the DNA level (Table 2) that indicated a potential loss or gain of DNA content. The extent of these changes cannot be assessed solely by the SSR analysis, and therefore, a genome-wide anonymous screen was needed in order to determine its nature. Hence, we proposed to further screen these materials using a genome-wide diagnostic molecular tool that could both measure the extent of the DNA sequence change. The SSR assay allowed us to predict the potential haploid origin of the callus lines, but it was not enough to assess ploidy status. Therefore, AFLPs were selected as an appropriate method to further assess the extent of DNA changes as well as to infer the ploidy status of the callus lines as described in other crops.

\section{AFLP marker analysis}

In this study, anther derived callus lines from cassava genotype SM 1219-9 (donor plant) were compared by AFLP profiling to detect a difference at the genetic level that could diagnose the

Table 2 Simple sequence repeat alleles detected using six SSRY primer pairs for eight callus cell lines derived from the donor plant SM 1219-9

\begin{tabular}{|c|c|c|c|c|c|c|c|c|c|c|c|c|c|c|c|}
\hline \multirow{2}{*}{$\begin{array}{l}\text { Marker } \\
\text { Allele sample }\end{array}$} & \multicolumn{3}{|c|}{ SSRY 19} & \multicolumn{2}{|c|}{ SSRY 21} & \multicolumn{2}{|c|}{ SSRY 63} & \multicolumn{2}{|c|}{ SSRY 82} & \multirow[b]{2}{*}{$3^{\mathrm{a}}$} & \multicolumn{3}{|c|}{ SSRY 164} & \multicolumn{2}{|c|}{ SSRY 182} \\
\hline & 1 & 2 & $3^{\mathrm{a}}$ & 1 & 2 & 1 & 2 & 1 & 2 & & 1 & 2 & $3^{\mathrm{a}}$ & 1 & 2 \\
\hline Donor & 230 & 234 & & 180 & 188 & 300 & 312 & 209 & 226 & & 183 & 185 & & 254 & 256 \\
\hline C 1 & + & - & & - & + & + & - & + & - & & + & - & & + & - \\
\hline $\mathrm{C} 2$ & + & - & 206 & - & + & + & - & + & - & 211 & + & - & & + & - \\
\hline C 3 & + & - & & - & + & + & - & + & - & 211 & + & - & & + & - \\
\hline $\mathrm{C} 4$ & + & - & & - & + & + & - & + & - & & + & - & & + & - \\
\hline C 5 & $\mathrm{x}$ & $\mathrm{x}$ & & - & + & $\mathrm{x}$ & $\mathrm{x}$ & $\mathrm{x}$ & $\mathrm{x}$ & & $\mathrm{x}$ & $\mathrm{x}$ & & $\mathrm{x}$ & $\mathrm{x}$ \\
\hline C 6 & + & - & & - & + & + & - & + & - & & + & - & 157 & + & - \\
\hline $\mathrm{C} 7$ & + & - & & + & + & + & - & + & - & 211 & + & - & & + & - \\
\hline C 8 & $\mathrm{x}$ & $\mathrm{x}$ & & $\mathrm{x}$ & $\mathrm{x}$ & $\mathrm{x}$ & $\mathrm{x}$ & + & - & 211 & $\mathrm{x}$ & $\mathrm{x}$ & & $\mathrm{x}$ & $\mathrm{x}$ \\
\hline
\end{tabular}

Size and the distribution of the homozygous vs. heterozygous alleles of the selected SSRY markers are shown for the donor plant SM $1219-9$ and antherderived callus cell lines; + indicates presence of allele presence, while -, absence of allele

${ }^{a}$ An extra allele appeared in certain reactions of the analyzed calli indicating a chromosome deletion or rearrangement 


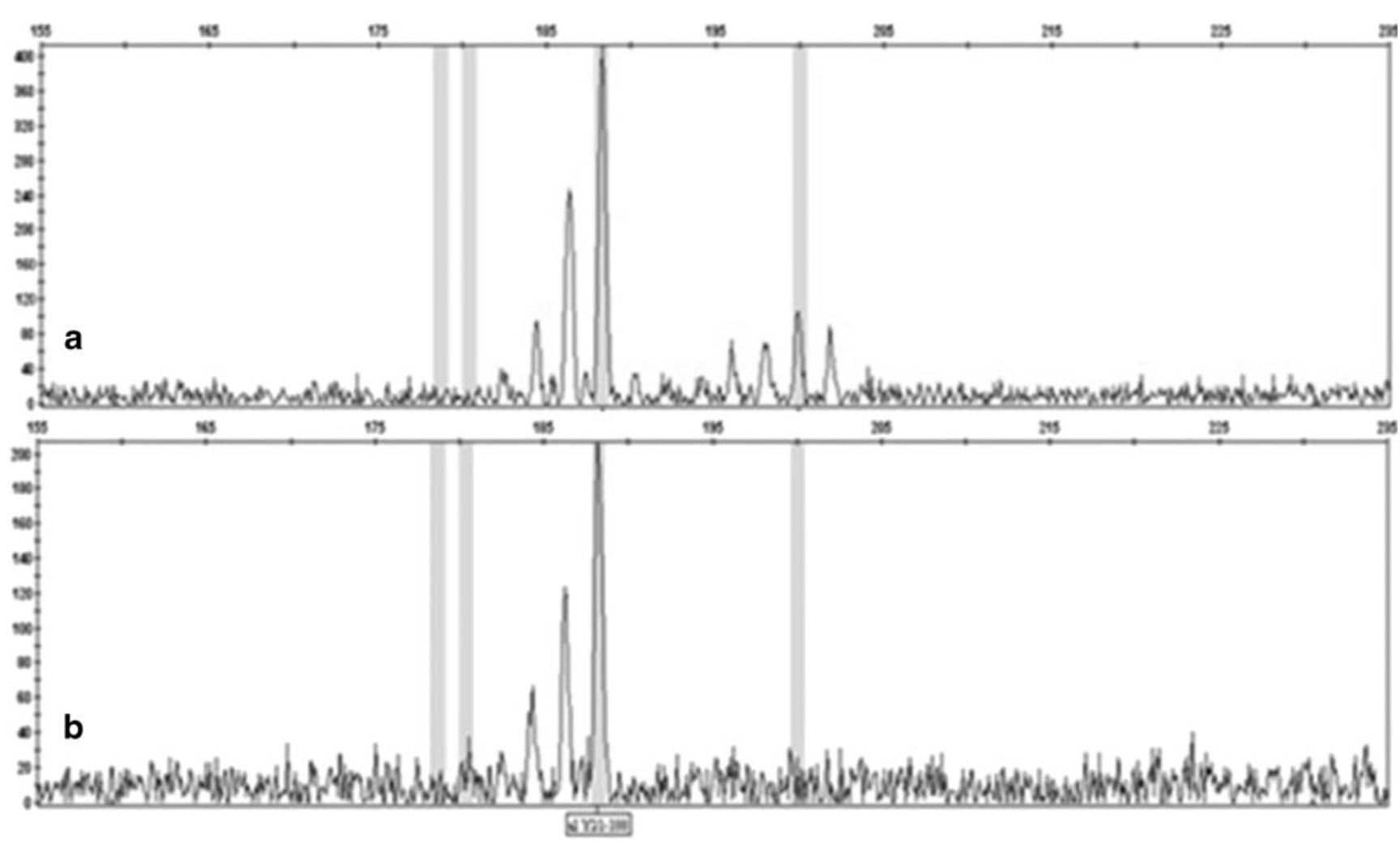

Fig. 7 Simple sequence repeat marker assay of the anther-derived calli of cassava (M. esculenta Crantz) to determine the origin of the callus lines. a The electrofluorogram obtained from the donor plants (SM 1219-9)

ploidy changes or mutation at the DNA level in the callus lines. The results of this analysis showed a noticeable decrease in the number of Eco RI/MseI-derived AFLP fragments in callus lines (32-52 AFLP bands) from the donor plant (71-76 AFLP alleles) (Fig. 8). Diploid callus lines were also observed in the same analysis, indicating that these are from the somatic cell structures as described in the section of flow cytometry analysis. In both cases, an unexpected increase in the number of AFLP alleles was observed, suggesting chromosome lagging during mitosis or DNA sequence mutation at the Eco RI/ Mse I restriction site during haploid induction treatment.

The increase in the number of AFLP bands above the range of that observed in the haploid or diploid materials suggested mutation or mixture of ploidy levels (42-52 or 80-95 AFLP bands, respectively) as indicated by the observed ratio values in Table 3. These results indicated that both heat and cold treatments triggered microspore embryogenesis but caused abnormalities at the DNA level. It has been reported that chromosome alterations can occur in callus cultures (Joachimiak et al. 1995) as a result of the stress treatment and culture conditions applied (Phillips et al. 1994). Even though the flow cytometry analysis is capable of showing changes at the ploidy level in the callus lines, it cannot be used to study the changes at the DNA level. using SSRY 21. b The electrofluorogram obtained from the antherderived calli showing the homozygous status of the cell line using the SSRY 21

\section{Discussion}

Anther pretreatment is one of the most critical factors to switch androgenesis induction (Germanà et al. 2011). A preliminary study revealed that the anthers subjected to heat shock $\left(34\right.$ and $\left.38^{\circ} \mathrm{C}\right)$ produced calli at a very low frequency (data not shown); therefore, further studies were conducted to test the feasibility of enhancing the induction frequencies by applying cold pretreatment $\left(10^{\circ} \mathrm{C}\right)$. Several authors, such as Zheng (2003), have highlighted the importance of pretreatment and the need for a specific stress treatment to trigger microspore development from the gametophytic to the sporophytic pathways. Cold and heat pretreatments have been highly effective in the induction of androgenesis in monocots such as rice (Oryza sativa) (Herath et al. 2009; Sen et al. 2011) and durum wheat (Triticum turgidum) (Slama-Ayed et al. 2010) as well as in dicots such as soybean (Glycine max) (Rodrigues et al. 2005) and Gentiana triflora (Pathirana et al. 2011). In addition, heat shock has been effective in monocots such as coconut (Cocos nucifera) (Perera et al. 2008a) and dicots such as cow cockle (Saponaria vaccaria) (Kernan and Ferrie 2005). The present study revealed that both cold and heat shocks were effective for triggering the microspore embryogenesis in cassava. Exposure of plants to elevated tem- 
Fig. 8 AFLP marker analysis (EACT-MCAT) of genotypes TMS 60444 and SM 1219-9 and 29 anther-derived callus cell lines from donor plant SM 1219-9 of cassava (M. esculenta Crantz). Lanes 1, 25, and 34 correspond to the molecular weight markers used. Lanes 2-22 correspond to the cell lines derived from coldpretreated $\left(10^{\circ} \mathrm{C}\right)$ anthers, while lanes 26-36 correspond to those from heat-pretreated $\left(38^{\circ} \mathrm{C}\right)$ ones. Lane 23 correspond to donor plant SM 1219-9, and lane 24, to the model transformation cassava genotype TMS 60444
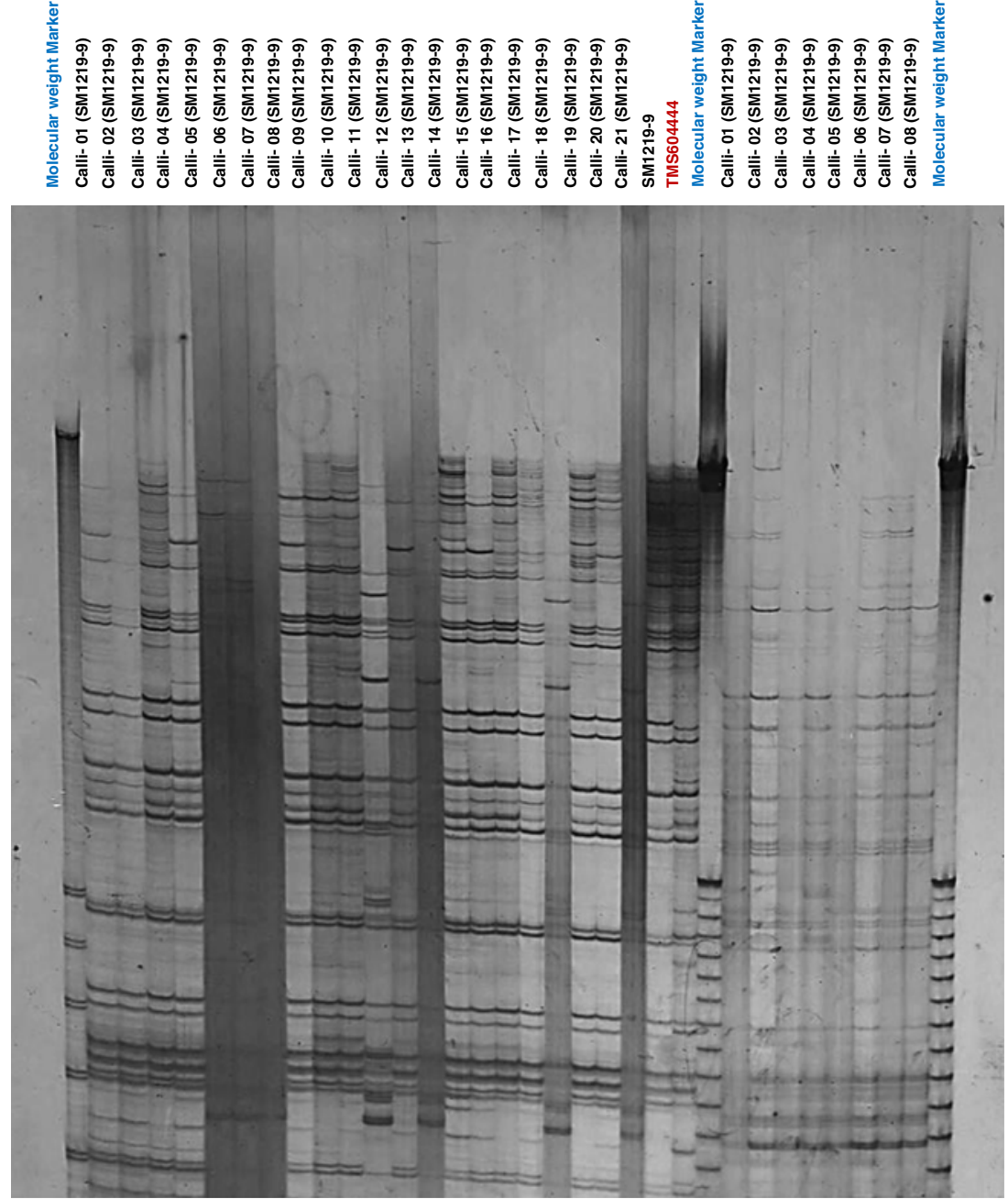

peratures results in a complex set of changes in gene expression that induce thermo-tolerance and improve cellular survival to subsequent stress (Gong et al. 1998). In Peruvian tomato (Lycopersicon peruvianum), it has been reported that the heat-shocked suspension cultures contained a considerable amount of the dominant small heat shock proteins which are structural proteins of newly forming granular aggregates in the cytoplasm, whose formation strictly depends on heat shock conditions (37 to $40{ }^{\circ} \mathrm{C}$ ) and the presence or simultaneous synthesis of heat shock proteins (Nover et al. 1983).

In the present study, high concentration of 2,4-D ( $8 \mathrm{mg} / \mathrm{l})$ induced the androgenic callus in cassava anthers; however, conversion of the embryos derived from those calli was shown to be difficult. In in vitro culture protocols, 2,4-D is a commonly used auxin; however, in most cases, low concentrations (less than $4 \mathrm{mg} / \mathrm{l}$ ) were used to induced androgenesis in different crops as in triticale (Pauk et al. 2000) and G. max (Oliveira et al. 1998). Rodrigues et al. (2004) reported that the high 2,4-D concentration $(10 \mathrm{mg} / \mathrm{l})$ significantly increased the induction of callogenic response in the somatic tissues of the anther; however, this had no effect on microspore embryogenesis. Thick exine present in cassava may lower the penetration efficiency of the medium components into the microspore; thus, only higher concentrations may be effective in the callogenesis induction. Water stress created by a high concentration of Phytagel in the culture medium converted the anther-derived friable calli into the globular embryos. The formation and conversion of embryos have also been reported by exposing to high Phytagel concentrations in Hevea brasiliensis (Rekha et al. 2007) and C. nucifera (Perera et al. 2011). Raghavan (2004) clearly reported that somatic embryogenesis induced in Arabidopsis cotyledonary embryos by the continuous culture in a 2,4-D-containing medium followed by their transfer to an auxin-free medium provided with a rapid and attractive system for studying gene activation during the embryogenic transformation of somatic cells and the subsequent maturation of early stage embryos. However, high concentration of auxin applied to induce androgenesis for a long period (about 3-4 months) may result in an unbalanced ratio of cellular auxin and cytokinin that regulate the de novo organ regeneration. Ślesak et al. (2005) reported that longer exposure to auxin caused poor formation of compact calli, and 
Table 3 AFLP analysis of anther-derived calli cell lines

\begin{tabular}{|c|c|c|c|c|c|c|c|c|c|}
\hline \multirow[t]{2}{*}{ Analyzed material } & \multicolumn{6}{|c|}{ AFLP analysis } & \multicolumn{3}{|c|}{ Comparison of analysis } \\
\hline & Total $^{\mathrm{a}}$ & Shared $^{\mathrm{b}}$ & Non-shared & Polymorphism (\%) ${ }^{\mathrm{c}}$ & Expected ratio $^{\mathrm{d}}$ & Observed ratio $^{\mathrm{e}}$ & AFLP & $\begin{array}{l}\mathrm{FCM} / \\
\mathrm{SSR}\end{array}$ & Origin of the callus \\
\hline TMS $60444^{\mathrm{f}}$ & 71 & 62 & 9 & 12.7 & 1 & 0.9 & DP & NA & \\
\hline SM 1219-9 & 76 & 76 & 0 & 0.0 & 1 & 1.0 & DP & DP & \\
\hline Cold C $1^{\mathrm{h}}$ & 77 & 66 & 11 & 14.3 & 1 & 1.0 & DP & DP & Somatic \\
\hline Cold C 2 & 61 & 54 & 7 & 11.5 & 0.7 & 0.8 & $\mathrm{DP}$ & $\mathrm{DP}$ & Somatic \\
\hline Cold C 3 & 83 & 71 & 12 & 14.5 & 1 & 1.1 & MP & DP & Somatic \\
\hline Cold C 4 & 95 & 69 & 26 & 27.4 & 1 & 1.3 & MP & MP & Haploid (somatic) \\
\hline Cold C 5 & 51 & 36 & 15 & 29.4 & 0.5 & 0.7 & HP & MP & Haploid (partial SD) \\
\hline Cold C 6 & 52 & 39 & 13 & 25.0 & 0.5 & 0.7 & $\mathrm{HP}$ & $\mathrm{DP}$ & Haploid (complete SD) \\
\hline Cold C 7 & 32 & 27 & 5 & 15.6 & 0.4 & 0.4 & $\mathrm{HP}$ & HP & Haploid \\
\hline Cold- C 8 & 85 & 71 & 14 & 16.5 & 1 & 1.1 & MP & MP & Haploid (somatic) \\
\hline Cold C 9 & 76 & 69 & 7 & 9.2 & 1 & 1.0 & DP & HP & Haploid (somatic) \\
\hline Cold- C 10 & 77 & 70 & 7 & 9.1 & 1 & 1.0 & $\mathrm{DP}$ & MP & Haploid (somatic) \\
\hline Cold C 11 & 74 & 67 & 7 & 9.5 & 1 & 1.0 & DP & MP & Haploid (somatic) \\
\hline Cold C 12 & 64 & 58 & 6 & 9.4 & 1 & 0.8 & $\mathrm{DP}$ & HP & Haploid (somatic) \\
\hline Cold C 13 & 44 & 30 & 14 & 31.8 & 0.39 & 0.6 & HP & HP & Haploid \\
\hline Cold C 14 & 84 & 68 & 16 & 19.0 & 1 & 1.1 & MP & $\mathrm{DP}$ & Somatic \\
\hline Cold C 15 & 74 & 64 & 10 & 13.5 & 1 & 1.0 & DP & $\mathrm{DP}$ & Somatic \\
\hline Cold C 16 & 73 & 67 & 6 & 8.2 & 1 & 1.0 & $\mathrm{DP}$ & $\mathrm{DP}$ & Somatic \\
\hline Cold C 17 & 74 & 67 & 7 & 9.5 & 1 & 1.0 & $\mathrm{DP}$ & $\mathrm{DP}$ & Somatic \\
\hline Cold C 18 & 33 & 27 & 6 & 18.2 & 0.36 & 0.4 & HP & $\mathrm{DP}$ & Haploid (complete SD) \\
\hline Cold C 19 & 76 & 73 & 3 & 3.9 & 1 & 1.0 & $\mathrm{DP}$ & HP & Haploid (somatic) \\
\hline Cold C 20 & 80 & 70 & 10 & 12.5 & 1 & 1.1 & MP & $\mathrm{HP}$ & Haploid (somatic) \\
\hline Cold C 21 & 32 & 26 & 6 & 18.8 & 0.3 & 0.4 & HP & HP & Haploid \\
\hline Heat $\mathrm{C} 1^{\mathrm{i}}$ & 36 & 31 & 5 & 13.9 & 0.4 & 0.5 & HP & HP & Haploid \\
\hline Heat C 2 & 42 & 35 & 7 & 16.7 & 0.5 & 0.6 & HP & HP & Haploid \\
\hline Heat C 3 & 35 & 31 & 4 & 11.4 & 0.4 & 0.5 & HP & HP & Haploid \\
\hline Heat C 4 & 38 & 33 & 5 & 13.2 & 0.4 & 0.5 & HP & HP & Haploid \\
\hline Heat C 5 & 33 & 30 & 3 & 9.1 & 0.4 & 0.4 & HP & HP & Haploid \\
\hline Heat C 6 & 43 & 34 & 9 & 20.9 & 0.4 & 0.6 & HP & HP & Haploid \\
\hline Heat C 7 & 42 & 33 & 9 & 21.4 & 0.4 & 0.6 & HP & HP & Haploid \\
\hline Heat C 8 & 35 & 30 & 5 & 14.3 & 0.4 & 0.5 & HP & HP & Haploid \\
\hline
\end{tabular}

The origin cell lines were determined by comparing the results gained from the analysis of AFLPs with flow cytometry and SSR marker analysis $D P$ diploid, $H P$ haploid, $M P$ mixoploids, $N A$ not analyzed, $S D$ spontaneous diploidization

${ }^{\text {a }}$ The total number of AFLP alleles

${ }^{\mathrm{b}}$ The no. of AFLPs shared with the SM 1219-9

${ }^{\mathrm{c}}$ The percentage of non-shared alleles over total alleles

${ }^{\mathrm{d}}$ The ratio of shared alleles over total alleles of the SM 1219-9

${ }^{\mathrm{e}}$ The ratio of total number alleles per genotype over the total number of alleles in SM 1219-9

${ }^{\mathrm{f}}$ TMS 60444 is the model genotype that is commonly used for the transformation research in cassava, and it was used as the positive control

${ }^{\mathrm{g}} \mathrm{SM} 1219-9$ is the donor genotype from which the anthers were collected for the induction of androgenesis

${ }^{\mathrm{h}}$ Callus cell lines (1-21) derived from the anthers pretreated at $10^{\circ} \mathrm{C}$

${ }^{\mathrm{i}}$ Callus cell lines (1-8) derived from the anthers pretreated at $38^{\circ} \mathrm{C}$

no roots and only one shoot formed on explants after 28 days of exposure to auxin in rape explants. On the other hand, the sporadic shoot and root formation could be the evidence for alternative organogenesis from the contaminated somatic 
callus, whereas the haploid cell suppressed the regeneration capacity; however, further studies should be conducted to test this hypothesis.

The histological analysis clearly indicated that the temperature pretreatments (cold or heat) and the conditions applied triggered the sporophytic development in the microspores of cultured anthers. Furthermore, among the cultured anthers containing different microspore developmental stages, miduninucleate stage responded for induction. Microspores in the anthers followed three routes; many microspores immediately arrested or died; a few continued towards becoming mature pollen by accumulating starch and proteins, and a few others were induced to divide. The characteristics of microspores undergoing reprogramming, significant enlargement of the microspore, reposition of the nucleus to the cell center, clearing of the cytoplasm, and the breaking of a large vacuole into smaller fragments (as shown by Touraev et al. 2001) were all observed in the first MCS developmental pathway. Contrastingly, in the second MCS developmental pathway, only the latter two processes were observed. The first indication and a characteristic feature of the onset of the embryogenic program, a symmetric division (Germanà et al. 2006; Seguí-Simarro and Nuez 2008) that is rarely found in the normal gametophytic development, could be identified in both pathways. MCSs containing numerous small nuclei are also observed in loquat (Eriobotrya japonica Lindl.) proembryos (Germanà et al. 2006).

In anther cultures, there is a higher possibility of getting calli with the different ploidy levels. Once the plant regeneration protocol is optimized, the callus lines with the haploid peaks are directly suitable for hybrid breeding programs after doubling the chromosomes, whereas the others require a further analysis to confirm their haploid origin. The homozygous diploids could be attributed to the formation of doubled haploids by spontaneous chromosome doubling caused by endomitosis/endoreduplication. The heterozygous diploids could result from the fusion of nuclei in two microspores (Antoine-Michard and Beckert 1997), an unreduced microspore (Ishizaka 1998), or from somatically originated calli from the anther wall, connective tissue, and filament, despite that they were removed from the cultures to avoid mixing them with the microspore-originated calli. The heterozygous vs. homozygous lines can be identified by SSR marker analysis (Perera et al. 2008b). Heterozygous diploids are undesirable products of anther culture and, as a result, are routinely discarded. The mixed profiles referred to as mixoploidy arise when more than one ploidy state is present in the sample, occurring frequently in tissue-cultured materials due to endoreduplication in only some of the cells of the callus mass. In culture medium, these polyploid cells sometimes have a selective advantage and, over time, become dominant in the culture. In a typical cell cycle, DNA duplication happens in the "S" phase and is followed by nuclear division in the "M" phase. However, the coupling of these phases is not always strictly followed, and occasionally, two S phases occur between subsequent $\mathrm{M}$ phases. The result is doubling of the cell DNA content. Mixoploids have also been reported in the other anther-cultured crops such as the Formosa lily (Lilium formosanum) (Han and Niimi 2005). In anther cultures, however, some cells will be derived from microspores, and others, from the somatic tissues, which are mixed together when proliferating. In the current study, even though the somatically derived calli were routinely discarded, the remaining traces of calli multiplied vigorously and could have mixed with the haploid-derived calli. The endoreduplication of the cells in the haploid calli giving rise to the doubled haploids was reported by Mishiba et al. (2001). This was probably associated with the high concentration of 2,4-D in the media, which can induce increases in ploidy levels. Lur and Setter (1993) reported that an abrupt increase in auxin induces cellular differentiation events in endosperm in maize, including endoreduplication. In cassava, androgenesis could be induced by using a higher level of 2,4-D ( $8 \mathrm{mg} / \mathrm{l})$. Weber et al. (2008) also reported that 2,4-D has an endoreduplication-enhancing effect in all calli in Datura stramonium and Hyoscyamus niger.

AFLP analysis was used as a molecular tool to identify differences in the numbers of AFLP bands as an indicator of ploidy level. AFLPs have been reported capable of detecting differences in ploidy levels in cotton (Becerra Lopez-Lavalle and Brubaker 2007). In cassava, AFLPs have been used to study the genetic relationships (Roa et al. 1997) and to generate the linkage maps (Kunkeaw et al. 2010); however, they have not been yet tested in in vitro derived cell lines. The results displayed by the AFLP analysis are consistent with the expectation that more AFLP fragments will be resolved from larger genomes (Han et al. 1999; van Heusden et al. 2000; Becerra Lopez-Lavalle and Brubaker 2007). In this study, it is expected that haploid cell lines in cassava be proportionally half the $2 \mathrm{C}$ genome content of the species $(1.67 \mathrm{pg} / \mathrm{cell}$ ) (Awoleye et al. 1994). The flow cytometry analysis suggested haploid, diploid, and mixoploid status of the callus cell lines consistent with the results obtained by the AFLP analysis. However, the large percentage polymorphism observed in these cell lines (3.9 to $31.8 \%$ ) indicated that haploid- or diploid-induced tissues underwent significant changes at the DNA level as revealed by the AFLP data (Table 3). Even though the AFLP analysis allowed the identification of the ploidy status and changes at the DNA level, further characterization of those changes will be needed in order to understand how haploid cell induction cause DNA mutation and if those can also cause physiological changes at the reproductive level. Next-generation sequencing analysis may offer a more precise picture of the extent of the changes that undergo during the induced embryogenesis in the cassava microspores. Furthermore, this type of data will potentially allow for the identification of genomic regions involved in the regeneration of these cell lines. 


\section{Conclusions}

The present study clearly demonstrates the feasibility of producing microspore-derived calli using the heat- or coldpretreated cassava anthers. Heat pretreatment induced embryogenesis only in gametes, whereas cold pretreatment induced embryogenesis in both somatic and gametic cells. The morphological aspect such as the emergence of calli through the anther wall has a risk of determining them to be originated from the gametes, inferring the requirement of further analysis. Triggering the microspore embryogenesis was demonstrated by the histological analysis. The presence of multicellular microspores in the in vitro system developed here indicates the switch of sporophytic developmental pathway. Flow cytometric analysis revealed that the culture conditions used in this study lead to different ploidy levels, including haploid which is the first report in cassava. SSR and AFLP marker analysis are proven as tools for identifying the origin of calli in cassava anther culture for the first time. The knowledge generated in this study is a step towards improving the protocol for the regeneration of microspore-derived doubled haploid plants, and it will contribute to accelerate the developmental process.

Acknowledgments We gratefully acknowledge the financial support provided through the grant ID no. OPPGD1483 from the Bill and Melinda Gates Foundation. We thank Dr. Hernan Ceballos for launching the project, "Inbreeding in cassava through the production of doubled haploids," at CIAT; Dr. R Bicknell (Plant and Food Research, New Zealand) for the assistance in flow cytometry; Mr. J.D.J.S. Kularatne for the statistical analysis; and Ms. Tatiana Ovalle for the assistance in the molecular marker analysis.

Conflict of interest The authors declare that they have no conflict of interest.

Open Access This article is distributed under the terms of the Creative Commons Attribution License which permits any use, distribution, and reproduction in any medium, provided the original author(s) and the source are credited.

\section{References}

Antoine-Michard S, Beckert M (1997) Spontaneous versus colchicineinduced chromosome doubling in maize anther culture. Plant Cell Tiss Organ Cult 48:203-207

Awoleye F, van Duren M, Dolezel J, Novak FJ (1994) Nuclear DNA content and in vitro induced somatic polyploidization cassava (Manihot esculenta Crantz) breeding. Euphytica 76:195-202

Bassam BJ, Caetano-Anollés G, Gresshoff PM (1991) Fast and sensitive silver staining of DNA in polyacrylamide gels. Anal Biochem 196: $80-83$

Becerra Lopez-Lavalle LA, Brubaker CL (2007) Frequency and fidelity of alien chromosome transmission in Gossypium hexaploid bridging populations. Genome 50:479-491

Ceballos H, Okogbenin E, Pérez JC, Becerra LA, Debouck D (2010) Cassava. In: Bradshaw J (ed) Root and tuber crops. Springer, New York, pp 53-96
Chirinos M, Velásquez RS, Noguera A, Pérez M, Mata J, Polanco D (2006) Cultivo de anteras en dos clones de yucca. Agron Trop 56:633-641

Compton ME (1994) Statistical methods suitable for the analysis of plant tissue culture data. Plant Cell Tissue Organ Cult 37:217-242

Davis JP, Supatcharee N, Khandelwal RL, Chibbar RN (2003) Synthesis of novel starches in planta: opportunities and challenges. StarchStarke 55:107-120

Doyle J, Doyle J (1990) A rapid total DNA preparation procedure for fresh plant tissue. Focus 12:13-15

Dunwell JM, Wilkinson MJ, Nelson S, Wening S, Sitorus AC, Mienanti D, Alfiko Y, Croxford AE, Ford CS, Forster BP, Caligari PDS (2010) Production of haploids and doubled haploids in oil palm. BMC plant boil 10:218. doi:10.1186/1471-2229-10-218.

Germanà MA, Chiancone B, Guarda NL, Testillano PS, Risueño M-C (2006) Development of multicellular pollen of Eriobotrya japonica Lindl. through anther culture. Plant Sci 171:718-725

Germanà MA, Chiancone $\mathrm{B}$, Padoan $\mathrm{D}$, Bárány $\mathrm{I}$, Risueño $\mathrm{M}-\mathrm{C}$, Testillano PS (2011) First stages of microspore reprogramming to embryogenesis through anther culture in Prunus armeniaca L. Environ Exp Bot 71:152-157

Gong M, van der Luit A H, Knight MR, Trewavas AJ (1998) Heat-shockinduced changes in intracellular $\mathrm{Ca}^{++}$level in tobacco seedlings in relation to thermo tolerance. Plant Physiol 116: 429-437

Han D-S, Niimi Y (2005) Production of haploid and doubled haploid plants from anther-derived callus of Lilium formosanum. Acta Horticult 673:389-393

Han TH, van Eck HJ, De Jeu MJ, Jacobsen E (1999) Optimization of AFLP fingerprinting of organisms with a large-sized genome: a study on Alstroemeria spp. Theor Appl Genet 98:465-471

Herath HNI, Bandara DC, Samarajeewa PK, Wijesundara DSA (2009) Effect of low temperature pretreatment on anther culture in selected Indica, Japonica rice varieties and their inter sub-specific hybrids. Ceylon J Sci (Biol Sci) 38:11-16

Herrmann V (2012) Cassava: a 'rambo root' that can fight climate change in Africa. http://www.pukhtoonistangazette.com/news.php?news id $=10708 \&$ cat $i d=0$. Accessed 18 May 2012

Ishizaka H (1998) Production of microspore derived plants by anther culture of an interspecific F1 hybrid between Cyclamen persicum and C. purpurascens. Plant Cell. Tissue Organ Cult 54:21-28

Joachimiak A, Ilnicki T, Kowalska A, Przywara L (1995) Chromosome alterations in tissue culture cells of Allium fistulosum. Genetica 96: 191-198

Kernan Z, Ferrie AMR (2005) Microspore embryogenesis and the development of a double haploidy protocol for cow cockle (Saponaria vaccaria). Plant Cell Rep 25:274-280

Kunkeaw S, Tangphatsornruang S, Smith DR, Triwitayakorn K (2010) Genetic linkage map of cassava (Manihot esculenta Crantz) based on AFLP and SSR marker. Plant Breed 129:112-115

Lentini Z, Reyes P, Martinez C, Roca WM (1995) Androgenesis of highly recalcitrant rice genotypes with maltose and silver nitrate. Plant Sci 110:127-138

Liu MC, Chen WH (1978) Organogenesis and chromosome number in callus derived from cassava anthers. Can J Bot 56:1287-1290

Lur H-S, Setter TL (1993) Role of auxin in maize endosperm development. Timing of nuclear DNA endoreduplication, zein expression, and cytokinin. Plant Physiol 103:273-280

Mba REC, Stephenson P, Edwards K, Melzer S, Nkumbira J, Gullberg U, Apel K, Gale M, Tohme J, Fregene M (2001) Simple sequence repeat (SSR) markers survey of the cassava (Manihot esculenta Crantz) genome: towards an SSR-based molecular genetic map of cassava. Theor Appl Genet 102:21-31

Mishiba K, Okamoto T, Mii M (2001) Increasing ploidy level in cell suspension cultures of Doritaenopsis by exogenous application of 2,4-dichlorophenoxyacetic acid. Physiol Plant 112:142-148

Moh CC (1975) Induction of anther callus in cassava. Trop Root Tuber Crops Newsl 8:5-7 
Mukherjee A (1996) Embryogenesis and regeneration from cassava calli of anther and leaf. In: Proceedings of the second international scientific meeting, Bogor, Indonesia, 1:375-381

Mukherjee A, Naskar SK (2010) In vitro culture of isolated pollen of cassava: influence of boric acid and growth regulators in pollen embryogenesis. http://www.danforthcenter.org/iltab/cassavanet/ cbnv/abstracts/Session7/S7-21.htm. 6 September 2010

Murashige T, Skoog F (1962) A revised medium for rapid growth and bio-assays with tobacco tissue cultures. Physiol Plant 15:473-497

Nover L, Scharf KD, Neumann D (1983) Formation of cytoplasmic heat shock granules in tomato cell cultures and leaves. Mol Cell Biol 3: 1648-1655

Ochatt S, Zhang Y (1996) Haploid plants from pollen grains. Science 163:85-87

Oliveira LC, Kaltchuk-Santos E, Bodanese-Zanettini MH (1998) Efeito de reguladores de crescimento na androgênese da soja. Genet Mol Biol 21(suppl):232

Otto F (1990) DAPI staining of fixed cells for high-resolution flow cytometry of nuclear DNA. Methods Cell Biol 33:105-110

Pathirana R, Frew T, Hedderley D, Timmerman-Vaughan G, Morgan E (2011) Haploid and doubled haploid plants from developing male and female gametes of Gentiana triflora. Plant Cell Rep 30:1055-1065

Pauk J, Puolimatka M, Tóth KL, Monostori T (2000) In vitro androgenesis of triticale in isolated microspore culture. Plant Cell Tiss Organ Cult 61:221-229

Perera PIP, Hocher V, Verdeil J-L, Bandupriya HDD, Yakandawala DMD, Weerakoon LK (2008a) Androgenic potential in coconut (Cocos nucifera L.). Plant Cell. Tissue Organ Cult 92:293-302

Perera PIP, Perera L, Hocher V, Verdeil J-L, Yakandawala DMD, Weerakoon LK (2008b) Use of SSR markers to determine the anther-derived homozygous lines in coconut. Plant Cell Rep 27:1697-1703

Perera PIP, Kularatene JDJS, Weerakoon LK (2011) Effect of gelling agent and selective sub-culturing on hyperhydricity in antherderived coconut embryos. Int J Coconut Res Dev 27:27-37

Perera PIP, Quintero M, Dedicova B, Kularatne JDJS, Ceballos H (2013) Comparative morphology, biology and histology of reproductive development in three lines of Manihot esculenta Crantz (Euphorbiaceae: Crotonoideae). Ann Bot Plants 5:pls046. doi:10. 1093/aobpla/pls046

Phillips RL, Kaepplert SM, Olhoft P (1994) Genetic instability of plant tissue cultures: breakdown of normal controls. Proc Natl Acad Sci U S A 91:5222-5226

Raghavan V (2004) Role of 2,4-dichlorophenoxyacetic acid (2,4-D) in somatic embryogenesis on cultured zygotic embryos of Arabidopsis: cell expansion, cell cycling and morphogenesis during continuous exposure of embryos to 2,4-D. Am J Bot 91(11):1743-1756

Rampling LR, Harker N, Shariflou MR, Morell MK (2001) Detection and analysis systems for microsatellite markers in wheat. Aust J Agric Res 52:1131-1141

Rekha K, Jayashree R, Suhamakumari S, Sankariammal S, Thulaseedharan A (2007) Endosperm culture in Hevea brasiliensis. In: Keshvachndran $\mathrm{R}$ et al (eds) Recent trends in horticultural biotechnology. New India, New Delhi, pp 111-116
Roa AC, Maya MM, Duque MC, Tohme J, Allem AC, Bonierbale MW (1997) AFLP analysis of relationships among cassava and other Manihot species. Theor Appl Genet 95:741-750

Rodrigues LR, Forte B de C, Oliveira JMS, Mariath JEA, BodaneseZanettini MH (2004) Effects of light conditions and 2,4-D concentration in soybean anther culture. Plant Growth Regulation 44:125131

Rodrigues LR, Oliverira JMS, Mariath JEA, Iranco LB, BodaneseZanettini MH (2005) Anther culture and cold treatment of floral buds increased symmetrical and extra nuclei frequencies in soybean pollen grains. Plant Cell Tissue Organ Cult 81:101-104

SAS Institute Inc (1999) SAS/STAT user's guide, version 7-1. SAS Institute Inc., Cary

Schuelke M (2000) An economic method for the fluorescent labeling of PCR fragments. Nat Biotechnol 18:233-234

Seguí-Simarro JM, Nuez F (2008) How microspores transform into haploid embryos: changes associated with embryogenesis induction and microspore-derived embryogenesis. Physiol Plant 134:1-12

Sen C, Singh RP, Singh MK, Singh HB (2011) Effect of cold pretreatment on anther culture of Boro rice hybrids. Int J Plant Reprod Biol 3:69-73

Slama-Ayed O, De Buyser J, Picard E, Trifa Y, Amara HS (2010) Effect of pre-treatment on isolated microspores culture ability in durum wheat (Triticum turgidum subsp. Durum Desf.). J Plant Breed Crop Sci 2:30-38

Ślesak H, Popielarska M, Goralski G (2005) Morphological and histological aspects of 2,4-D effects on Rape explants (Brassica napus L. cv kana) cultured in vitro. Acta Biologica Cracoviensia Series Botanica 47:219-226

Touraev A, Pfosser M, Heberle-Bors E (2001) The microspore: a haploid multipurpose cell. Adv Bot Res 35:53-109

van Heusden AW, van Ooijen JW, Vrielink-van Ginkel R (2000) A genetic map of an interspecific cross in Allium based on amplified fragment length polymorphism (AFLP (TM)) markers. Theor Appl Genet 100:118-126

Vos P, Hogers R, Bleeker M, Reijans M, van de Lee T, Hornes M, Friters A, Pot J, Paleman J, Kuiper M, Zabeau M (1995) AFLP: a new technique for DNA fingerprinting. Nucleic Acids Res 23(21):44074414

Weber J, Georgiev V, Pavlov A, Bley T (2008) Flow cytometric investigations of diploid and tetraploid plants and in vitro cultures of Datura stramonium and Hyoscyamus niger. Cytometry A 73:931939

Woodward B, Puonti-Kaerlas J (2001) Somatic embryogenesis from floral tissue of cassava (Manihot esculenta Crantz). Euphytica 120:1-6

Xi S-L, Feng D, Pan L-H (2009) Callus induction of anther in cassava (Manihot esculenta L.). Guangxi Agric Sci 40:124-127

Zheng MY (2003) Microspore culture in wheat (Triticum aestivum) doubled haploid production via induced embryogenesis. Plant Cell Tissue Organ Cult 73:213-230

This paper has been reviewed by Ranjith Pathirana. 